\title{
IN VITRO STUDIES TO ASSESS THE ANTIDIABETIC POTENTIAL OF SCHLEICHERA OLEOSA (LOUR) OKEN LEAVES
}

\section{SOUNDARARAJAN MUTHUKRISHNAN,* SIVAKKUMAR T}

\author{
Department of Pharmacy, Annamalai University, Chidambaram, Tamil Nadu, India. Email: s.muthukrishnan.smk@gmail.com
}

Received: 18 March 2017, Revised and Accepted: 17 April 2017

\section{ABSTRACT}

Objective: The aim of this research is to establish the antidiabetic properties of sequential extracts of Schleichera oleosa (lour) Oken leaves thru $\alpha$-amylase and $\alpha$-glucosidase inhibitory assay.

Methods: The extracts of $S$. oleosa (Lour) Oken were prepared by continuous hot percolating the dried powder of the plant leaves. The various solvents were used for the extraction and qualitative assay for the phytochemical test using standard protocols. Different concentration $(1,2,4,6,12$, 25 , and $50 \mathrm{mg} / \mathrm{ml}$ ) of sequential extracts of $S$. oleosa leaves were used to assess the in vitro $\alpha$-amylase and $\alpha$-glucosidase inhibitory assay by Bernfeld and Apostolidis method.

Results: In the $\alpha$-amylase assay, the ethanolic extract produced $52.76 \%$ inhibition at $4 \mathrm{mg} / \mathrm{ml}$ concentration, but in ethyl acetate and aqueous extracts case $50 \%$ inhibition attained only at the concentration of $50 \mathrm{mg} / \mathrm{ml}$, and acarbose $0.9 \mathrm{mg} / \mathrm{ml}$ was found $89.24 \%$ inhibition. In the $\alpha$-glucosidase assay, the all extracts show the decent inhibitory effect in $50 \mathrm{mg} / \mathrm{ml}$. The ethanolic and aqueous extracts exhibited a higher inhibitory effect $72.64 \%$ and $59.44 \%$ than other extracts at the concentration of $50 \mathrm{mg} / \mathrm{ml}$, respectively, while acarbose $0.9 \mathrm{mg} / \mathrm{ml}$ was producing $86.24 \%$ inhibition. This result indicates that the inhibition of ethanolic and aqueous extracts on the activity from $\alpha$-amylase and $\alpha$-glucosidases is much more potent than that of other extracts.

Conclusion: This study revealed that ethanolic and aqueous extracts showed the high content of polyphenols and flavonoids, which was blamed for the $\alpha$-amylase and $\alpha$-glucosidases inhibition. Hence, it deserved to elucidate specific components and to evaluate the antidiabetic effect using in vivo animal model.

Keywords: Phytochemical studies, Flavonoids, $\alpha$-amylase, $\alpha$-glucosidase, Acarbose, Dinitro salicylic acid, p-nitrophenyl- $\alpha$-D-glucopyranoside.

(C) 2017 The Authors. Published by Innovare Academic Sciences Pvt Ltd. This is an open access article under the CC BY license (http://creativecommons. org/licenses/by/4. 0/) DOI: http://dx.doi.org/10.22159/ajpcr.2017.v10i7.18549

\section{INTRODUCTION}

Diabetes mellitus (DM) is the most typical endocrine disorder, in which carbohydrate and lipid metabolisms are improperly controlled by insulin. There are principally two types of DM, Type I diabetes results from the inadequate synthesis of insulin by $\beta$-cells of the pancreas, while Type II diabetes is characterized primarily by insulin resistance (a condition during which peripheral cells do not respond ordinarily to insulin) or $\beta$-cell dysfunction [1]. The main clinical signs of DM are polydipsia, polyuria, polyphagia and weight loss, along with high glucose level in blood and urine. It is a progressive metabolic disorder of glucose metabolism that eventually leads to retinopathy, nephropathy, neuropathy, microangiopathy and increased risk of micro- and macrovascular changes causing secondary complications that are difficult to manage [2].

The therapeutic strategies for the treatment of Type II, diabetes contains the reduction of the insulin demand; stimulate the secretion of endogenous insulin, enhancement of the action of insulin at the target tissues, and the inhibition of degradation of polysaccharides [3].

Recently, retardation of carbohydrate-hydrolyzing enzymes, such as $\alpha$-glucosidase and $\alpha$-amylase, are becoming a promising effective approach to control Type II DM through the mechanism of preventing the absorption of glucose [4]. Several inhibitors of $\alpha$-amylase and $\alpha$-glucosidase have been isolated from medicative plants to function another drug with increased efficiency and lesser adverse effects than existing synthesized medication [5].

Many oral hypoglycemic agents have been available to treat DM. However, these synthetic agents are perpetually related to certain problems, such as adverse side effects, decreased efficacy over time, ineffectiveness against some long-term diabetic complications [6].

The hunting for novel pharmacologically active agents achieved by screening natural sources or their extracts will cause effective and precise inhibitors for $\alpha$-amylase. The $\alpha$-glucosidase inhibitors such as acarbose that can also inhibit pancreatic $\alpha$-amylase revealed that it's delayed or prevented the diabetic complication such as renal, retinal, lens and neurological changes, and the development of Ischemic myocardial lesions [7].

In the long-term management of diabetes, with acarbose is well tolerated and might progress glycemic management as monotherapy, additionally as together with some other drugs. The abdominal distention, flatulence, meteorism, and possibly diarrhea are main adverse effects of acarbose [8]. The exploration for safer, specific, and effective hypoglycemic agents has sustained to be a crucial space of inquiry with herbal extracts from promptly offered traditional medicinal plants, providing the nice potential for discovery of new antidiabetic drugs [9].

Schleichera oleosa (Lour) Oken, usually recognized as Lac tree or Kusum, is a forest tree class of thetropical and subtropical region. The tree is utilized for multifarious purposes and manufacture of natural, decomposable and commercially imperative lac resins that serve as a livelihood support to millions of poor farmers.

It also has many medicinal uses and is used in folkloric medicine for numerous indications. The powdered seeds are applied to wounds and ulcers of cattle to remove the maggots. The bark is used as an 
astringent and against skin inflammations, ulcers, itching, acne, and other skin infections [10]. It is generally used as an analgesic, antibiotic and against dysentery [11]. Recently, it was reported that the bark along with water is used to treat menorrhea [12].

The search for harmless, exact, and effective antihyperglycemic agents have sustained to be an imperative area of exploration with natural plants from readily available traditional medicinal plants proposing great potential for discovery of new antidiabetic drugs.

Thus, the aim of this research is to establish the antidiabetic properties thru $\alpha$-amylase and $\alpha$-glucosidase inhibitory activities of sequential extracts of $S$. oleosa leaves.

\section{METHODS}

\section{Collection and authentication}

Fresh leaves of S. oleosa were collected during May 2016 from the forest regions of Kanyakumari District, Tamil Nadu. The plant material was identified and authenticated by Mr. V. Chelladurai, Research officer-Botany, Central Council for Research in Ayurveda and Siddha (Government of India), Tirunelveli, Tamil Nadu. The voucher specimens were preserved in the department herbarium library (PS-08/14/1/5/16).

\section{Processing of the sample}

Fresh leaves of plants were washed, well-using tap water and twice using distilled water and it was dried in the shade for 10-15 days, at an ambient temperature of $33^{\circ} \mathrm{C}$. After drying, leaf materials were crushed into small pieces. The dried samples were ground properly, to obtain the powdered into coarse state and stored at room temperature till their use in the experiment [13].

\section{Preparation of extracts}

The dried, powdered leaf material (500 g) was subjected to successive solvent extraction using different solvents (petroleum ether, chloroform (Cf), ethyl acetate (Ea), ethanol, and water) in the increasing order of polarity by a hot percolation method using soxhlet apparatus except for aqueous extraction. Then, the extracts were distilled and recover the solvent and evaporated to dryness using a rotary vacuum evaporator [14].

\section{Phytochemical screening of the plant material}

Phytochemical screening was done in analyzing the presence of secondary metabolites that are responsible for curing ailments. The phytochemical screening of the plant extract was carried out for all the extracts, as per the standard methods $[15,16]$.

\section{Drugs and chemicals}

The $\alpha$-amylase, $\alpha$-glucosidase, dinitro salicylic acid (DNS), p-nitrophenyl- $\alpha$-D-glucopyranoside (p-NPG), chemicals were bought from Sigma-Aldrich Co Ltd., Irvin, UK. The standard drug acarbose gift sample got from orchid chemicals and pharmaceuticals, India. The other chemicals and solvents used were of analytical grade purchased from Nice chemicals, India.

\section{In vitro $\alpha$-amylase inhibitory activity}

The $\alpha$-amylase inhibitory activity was determined according to the Bernfeld method [17]. Briefly, the sample $500 \mu \mathrm{l}$ and the $\alpha$-amylase $500 \mu \mathrm{l}(2 \mathrm{Unit} / \mathrm{ml}$ ) were mixed and pre-incubated in $20 \mathrm{mM}$ sodium phosphate buffer $(\mathrm{pH} 6.7)$ for 5 minutes at $37^{\circ} \mathrm{C}$. Then, $1 \mathrm{ml}$ of $0.2 \%(\mathrm{w} / \mathrm{v})$ starch dissolved in the buffer was more to the reaction mixture to make a total volume of $2 \mathrm{ml}$, and therefore the whole mixture was incubated for 5 minutes at $37^{\circ} \mathrm{C}$. Once the incubation, $1 \mathrm{ml}$ of DNS color reagent was added and placed in a boiling bathtub for specifically 5 minutes. And then, this mixture was cooled on ice to room temperature and added another $6 \mathrm{ml}$ of deionized water. The $\alpha$-amylase activity was determined by measuring the absorbance of the mixture at $540 \mathrm{~nm}$ against a control containing a buffer solution in place of the enzyme solution $[18,19]$.

\section{In vitro $\alpha$-glucosidase inhibitory activity}

The $\alpha$-glucosidase inhibitory activity was determined using the substrate p-NPG that might be hydrolyzed by $\alpha$-glucosidase to release the product p-nitrophenol and then checked by a color reagent at $405 \mathrm{~nm} .50 \mu \mathrm{l}$ dilutions of the extracts or monomeric compounds were mixed with $10 \mu \mathrm{l}$ of $\alpha$-glucosidase $(0.9 \mathrm{mg} / \mathrm{ml})$ in $0.1 \mathrm{M}$ phosphate buffer $(\mathrm{pH}=6.8)$ solution. Then, $400 \mu \mathrm{l}$ of $0.1 \mathrm{M}$ phosphate buffer $(\mathrm{pH}=6.8)$ was added. After incubated at $37^{\circ} \mathrm{C}$ for 10 minutes, $10 \mu \mathrm{l}$ of $20 \mathrm{mM}$ p-NPG in $0.1 \mathrm{M}$ phosphate buffer $(\mathrm{pH}=6.8)$ solution was added. The reaction was stopped by adding $400 \mu \mathrm{l} 0.1 \mathrm{M} \mathrm{NaCO}_{3}$, and mixtures were incubated at $37^{\circ} \mathrm{C}$ for 75 minutes before reading the absorbance at $405 \mathrm{~nm}$ in the spectrophotometer [20]. The control sample included all other reagents and $\alpha$-glucosidase, but without the test extracts sample.

In both assays, acarbose was used as a positive control. The assay was performed in 6 findings and the result which was found the mean and standard error of mean. The results were expressed as percentage inhibition of enzyme action and calculated according to the following equation:

Percentage Inhibition $=100 *(\mathrm{Ac}-\mathrm{As}) / \mathrm{Ac}$

(Ac - Mean absorbance value of the control, As - Mean absorbance value of the sample)

The reaction blank mixture contained the same volume of the buffer solution instead of the sample. Where Ac was the optical density of the reaction control; As was the optical density of the reaction in the presence of both enzyme and extract sample [21].

\section{RESULTS AND DISCUSSION}

\section{Extraction of plant material}

The aerial parts of the plant were a shade dried and made into coarse powder. The coarse powder was extracted by the continuous hot percolation method in soxhlet apparatus using various solvents in increasing polarity petroleum ether, $\mathrm{Cf}$, $\mathrm{Ea}$, and ethanol and water. Extracts were concentrated by the removal of solvent under reduced pressure and finally, the residue was dried in a vacuum. The percentage yields were such as petroleum extract $3.26 \% \mathrm{w} / \mathrm{w}$, Cf extract $1.35 \% \mathrm{w} / \mathrm{w}$, Ea extract $1.70 \% \mathrm{w} / \mathrm{w}$, ethanolic (Et) extract $7.73 \% \mathrm{w} / \mathrm{w}$, and aqueous (Aq) extract $4.21 \% \mathrm{w} / \mathrm{w}$ in Table 1.

\section{Qualitative phytochemical screening}

All the extracts were subjected to a preliminary phytochemical screening to identify the phytoconstituents using qualitative chemical reagents. The phytochemical tests revealed the presence of phytosterols in the all the extracts, alkaloids (Et, Aq), glycosides (Et, Aq), saponins (Et, Aq), phenolic compounds (Ea, Et, Aq), and flavonoids (Ea, Et, Aq).

Compared with petroleum ether and Cf extracts, most of the phytoconstituents present in the Ea, ethanolic and aqueous extracts. The results of preliminary phytochemical were given in Table 2.

\section{In vitro $\alpha$-amylase and $\alpha$-glucosidase inhibitory activity}

The $\alpha$-amylase and $\alpha$-glucosidase have been familiar as a therapeutic target for modulation of postprandial hyperglycemia, which is the initial metabolic abnormality to occur in type $2 \mathrm{DM}$. The inhibition of these enzymes would delay the digestion and absorption

Table 1: Extractive values of powdered leaves of S. oleosa

\begin{tabular}{llll}
\hline Extracts & Color & Consistency & $\begin{array}{l}\text { Percentage } \\
\text { yield }\end{array}$ \\
\hline Petroleum ether & Yellowish green & Solidify & 3.26 \\
Chloroform & Green & Solidify & 1.35 \\
Ethyl acetate & Greenish brown & Sticky & 1.70 \\
Ethanol & Brown & Thick viscous & 7.73 \\
Aqueous & Reddish brown & Solidify & 4.21 \\
\hline
\end{tabular}


Table 2: Qualitative phytochemical screening of successive extracts of powdered leaves of S. oleosa

\begin{tabular}{llllll}
\hline \multirow{2}{*}{ Compounds } & \multicolumn{7}{c}{ Observation } & & \\
\cline { 2 - 6 } & PET & CF & EA & ET & AQ \\
\hline Carbohydrates & - & - & - & + & + \\
Glycosides & - & - & - & + & + \\
Proteins and aminoacids & - & - & - & - & - \\
Alkaloids & - & - & - & + & + \\
Saponins & - & - & - & + & + \\
Phenolic compounds and tannins & - & - & + & + & + \\
Flavonoids & - & + & + & + & + \\
Phytosterols & + & + & + & + & + \\
Fixed oils and fats & - & - & - & - & - \\
Gums and mucilage & - & - & - & - & + \\
Volatile oil & - & - & - & - & - \\
Resin & - & - & - & - & - \\
\hline
\end{tabular}

S. oleosa: Schleichera oleosa, PET: Petroleum ether extract, CF: Chloroform extract, EA: Ethyl acetate extract, ET: Ethanolic extract, AQ: Aqueous extract

of carbohydrates and consequently suppress the postprandial hyperglycemia $[22,23]$.

The inhibitory effect of $S$. oleosa extracts on $\alpha$-amylase was investigated. Effects were compared with the markedly available inhibitor, acarbose. The results for $\alpha$-amylase inhibitory activity of the extracts were evaluated at seven different concentrations $(1,2,4,6,12,25$ and $50 \mathrm{mg} / \mathrm{ml}$ ) and acarbose $0.9 \mathrm{mg} / \mathrm{ml}$ are shown in Fig. 1. The ethanolic extract at $4 \mathrm{mg} / \mathrm{ml}$ produced $52.76 \%$ inhibition and $50 \%$ inhibition attained in Ea and aqueous extract only at the concentration of $50 \mathrm{mg} / \mathrm{ml}$ and acarbose $0.9 \mathrm{mg} / \mathrm{ml}$ were found $89.24 \%$ inhibition. The petroleum ether, Cf, and Ea extracts showed less inhibition compared to ethanol and aqueous extract. S. oleosa ethanolic and aqueous extracts exhibited a significant dose-dependent inhibition of $\alpha$-amylase activity compared to petroleum ether, Cf and Ea extracts. S. oleosa ethanolic extract exhibited a higher inhibitory effect $71.52 \%$ than acarbose (89.24\%).

In the $\alpha$-glucosidase assay, the all extracts show the decent inhibitory effect on $50 \mathrm{mg} / \mathrm{ml}$ concentration and the inhibitory effect of ethanolic extract in a dose-dependent manner, as shown in Fig. 2. The inhibition of ethanolic extract shown the increments were $10.68 \%, 26.38 \%$, $37.22 \%, 45.87 \%, 56.80 \%, 61.20 \%$, and $72.64 \%$ at the concentrations of $1,2,4,6,12,25$, and $50 \mathrm{mg} / \mathrm{ml}$. The ethanolic extract exhibited a higher inhibitory effect $72.64 \%$ than other extracts at the concentration of $50 \mathrm{mg} / \mathrm{ml}$. The aqueous extract showed $52.44 \%$ and $59.22 \%$ inhibitory activity at $25 \mathrm{mg} / \mathrm{ml}$ and $50 \mathrm{mg} / \mathrm{ml}$, respectively, while acarbose $0.9 \mathrm{mg} / \mathrm{ml}$ was producing $86.24 \%$ inhibition.

This result indicates that the inhibition of ethanolic and aqueous extracts on the activity from $\alpha$-amylase and $\alpha$-glucosidases is much more potent than that of other extracts. It is probably because of its higher polyphenol compounds, which has been demonstrated to possess an ability to bind to the active protein pocket of the enzyme [4,24]. Various assays also revealed that many plant polyphenols and flavonoids possess in vitro inhibitory activities of cholesterol esterase [25] and carbohydrate hydrolyzing enzymes $[26,27]$.

The $\alpha$-amylase and $\alpha$-glucosidase inhibitors have been useful as oral hypoglycemic drugs for the control of hypoglycemia in DM patients. Inhibition of this enzyme delay the overall carbohydrate digestion, it leads to the reduction in the rate of glucose absorption and consequently reducing postprandial plasma glucose rise [28].

According to this assay, S. oleosa active components were proven to be a strong inhibitor of these enzymes.

This study was designed to testify the potential antihyperglycemic activity of $S$. oleosa sequential extract by using in vitro enzyme assay.

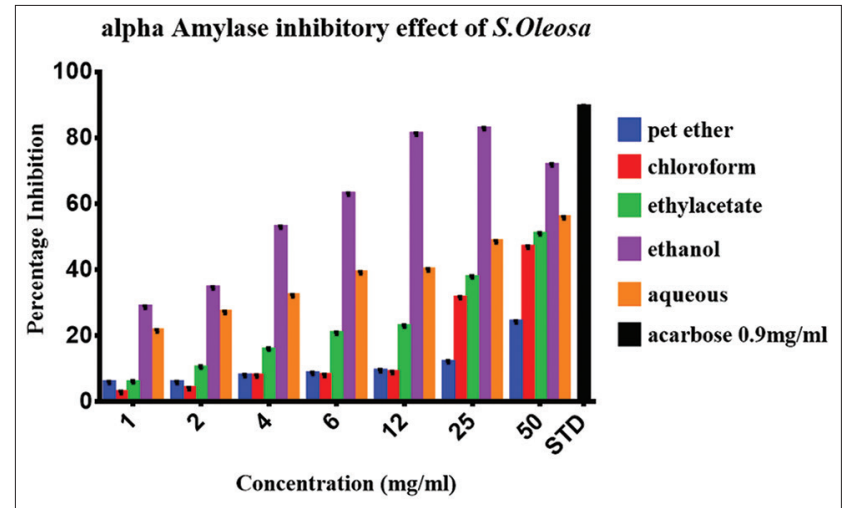

Fig. 1: Influence of different concentrations of Schleichera oleosa extract on $\alpha$-amylase activity in vitro. Each value was represented as mean $\pm S E M, n=6$ independent experiments

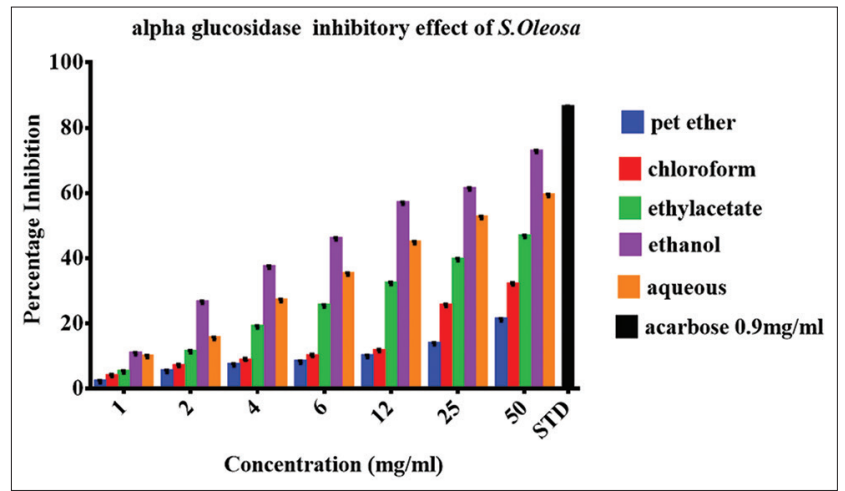

Fig. 2: Influence of different concentrations of $S$. oleosa extract on $\alpha$-glucosidase activity in vitro. Each value was represented as mean \pm SEM, $n=6$ independent experiments

The results of the in vitro $\alpha$-amylase and $\alpha$-glucosidase inhibition test revealed that ethanolic and aqueous extracts had a similar inhibitory effect with that of the standard drug acarbose.

These findings suggested that $S$. oleosa extract could decrease the postprandial glucose level by inhibiting the activity of $\alpha$-amylase and $\alpha$-glucosidase, which are vital enzymes in the breakdown of the compound carbohydrates into absorbable glucose in the food.

And recently, most reports revealed that polyphenols and flavonoids could effectively inhibit the action of $\alpha$-amylase and $\alpha$-glucosidase to reduce the absorption of carbohydrates from food. Hence, the polyphenols and flavonoids in S. oleosa might take the responsibility for the postprandial antihyperglycemic effect of $S$. oleosa extract. It was very interesting to point out that $S$. oleosa extract was more efficient for the complex with carbohydrates. This result was consistent with the finding that ethanolic and aqueous extract could inhibit both $\alpha$-amylase and $\alpha$-glucosidase since the digestion of carbohydrate involved both of these enzymes.

\section{CONCLUSION}

In conclusion, the potential antidiabetic effect of S. oleosa was well established. The possible underlying mechanisms of this outcome may be related with that $S$. oleosa could inhibit $\alpha$-amylase and $\alpha$-glucosidase activity to decrease the absorption of carbohydrates from food. Moreover, the leaves of S. oleosa extract might contain active constituents for the management of diabetes and a promising supply for the invention of antidiabetic agents. Hence, further investigations are deserved to elucidate specific components and their mechanisms of S. oleosa for its antidiabetic effect. 


\section{ACKNOWLEDGMENTS}

They authors acknowledged to Dr. K. Kannan, Professor, and Former Head, Department of Pharmacy, Annamalai University, for all facilities and support during the course of our research work. Our sincere thanks are due to Mr. A. Aranganathan and Mrs. Daisy for their kind assistance in the laboratory work and all other non-teaching staff for their kind cooperation in all possible ways.

\section{REFERENCES}

1. Wang T, Li X, Zhou B, Li H, Zeng J, Gao W. Anti-diabetic activity in Type 2 diabetic mice and $\alpha$-glucosidase inhibitory, antioxidant and anti-inflammatory potential of chemically profiled pear peel and pulp extracts (Pyrus Spp.). J Funct Foods 2015;13:276-88.

2. Kazeem MI, Adamson JO, Ogunwande IA. Modes of inhibition of a -amylase and a -glucosidase by aqueous extract of Morinda lucida Benth leaf. Biomed Res Int 2013;2013:527570.

3. Sales PM, Souza PM, Simeoni LA, Silveira D. A-amylase inhibitors: A review of raw material and isolated compounds from plant source. J Pharm Pharm Sci 2012;15(1):141-83.

4. Shobana S, Sreerama YN, Malleshi NG. Composition and enzyme inhibitory properties of finger millet (Eleusine coracana L.) seed coat phenolics: Mode of inhibition of $\alpha$-glucosidase and pancreatic amylase. Food Chem 2009;115:1268-73.

5. Matsui T, Ogunwande IA, Abesundara KJ, Matsumoto K. Antihyperglycemic potential of natural products. Mini Rev Med Chem 2006;6:349-56.

6. Wang HC, Cheng SJ. The syndrome of acute bilateral basal ganglia lesions in diabetic uremic patients. J Neurol 2003;250(3):948-55.

7. Kotowaroo MI, Mahomoodally MF, Gurib-Fakim A, Subratty AH. Traditional medicinal herbs and food plants have the potential to inhibit key carbohydrate hydrolyzing enzymes in vitro and reduce postprandial blood glucose peaks in vivo. Phytother Res 2006;20:228-31.

8. Klein G, Kim J, Himmeldirk K, Cao Y, Chen X. Antidiabetes and antiobesity activity of Lagerstroemia speciosa. Evid Based Complement Alternat Med 2007;4(4):401-7.

9. Prabhu AS, Ananthan G. Alpha-amylase inhibitory activities of ascidians in the treatment of diabetes mellitus. Bangladesh J Pharmacol 2014;9(4):498-500.

10. Iwasa S. Schleichera oleosa (Lour.) Oken. In: Faridah HI, Maesen LJ, editors. Plant Resources of South-East Asia No.11, Auxiliary Plants. Bogor, Indonesia: Prosea Foundation; 1997. p. 227-9.

11. Rout SD, Panda T, Mishra N. Ethno-medical plants used to cure different diseases by tribal of Mayurbhanj district of North Orissa. Ethnomed 2009;3:27-36.

12. Mahaptma SP, Sahoo HP. An ethano medico botanical study of Bolangi, Orissa, India: Native plant remedies against gynaecological diseases.
Ethanobot Lealf 2008;12:846-54

13. Khandekar U, Bobade A, Ghongade R. Evaluation of antioxident activity, in-vitro antimicrobial activity and phytoconstituents of Schleichera oleosa (Lour.) Oken. Int J Bio Pharm Res 2015;6:137-43.

14. Ahmad A, Husain A, Mujeeb M, Khan SA, Alhadrami HA, Bhandari A. Quantification of total phenol, flavonoid content and pharmacognostical evaluation including HPTLC fingerprinting for the standardization of Piper nigrum Linn fruits. Asian Pac J Trop Biomed 2015;5:101-7.

15. Trease GE, Evans WC. Pharmacognosy. $11^{\text {th }}$ ed. London: Bailliere Tindall Ltd.; 1978. p. 60-75.

16. Raman N. Phytochemical Techniques. New Delhi: New India Publishing Agency; 2006. p. 10-24

17. Bernfeld P. Amylases, alpha and beta. Methods in Enzymology. San Diego: Academic Press; 1955. p. 1149-58.

18. Wan LS, Chen CP, Xiao ZQ, Wang YL, Min QX, Yue Y, et al. In vitro and in vivo anti-diabetic activity of Swertia kouitchensis extract. J Ethnopharmacol 2013;147(3):622-30

19. Kalpana S, Ramakrushna B, Anitha S. Evaluation of in vitro antioxidant and $\alpha$-amylase inhibitory activity of Phyllanthus indofischeri Bennet. Int J Pharm Pharm Sci 2016;8:131-6.

20. Apostolidis E, Kwon YI, Shetty K. Inhibitory potential of herb, fruit, and fungal-enriched cheese against key enzymes linked to Type 2 diabetes and hypertension. Innov Food Sci Emerg Technol 2007;8:46-54

21. Wang T, Xia L, Bin Z, Hongfa L, Jie Z, Wenyuan G. Anti-diabetic activity in Type 2 diabetic mice and $\alpha$-glucosidase inhibitory, antioxidant and anti-inflammatory potential of chemically profiled pear peel and pulp extracts (Pyrus Spp). J Funct Foods 2015;13:276-88.

22. Lebovitz HE. Postprandial hyperglycaemic state: Importance and consequences. Diabetes Res Clin Pract 1998;40 Suppl: S27-8.

23. Yao Y, Cheng X, Ren G. A-Glucosidase inhibitory activity of proteinrich extracts from extruded adzuki bean in diabetic KK-Ay mice. Food Funct 2014;5(5):966-71.

24. Muthukrishnan S. In silico docking studies of cholesterol esterase inhibitory activity of commercially available flavonoids. Int J Pharm Educ Res 2014;1:1-7.

25. Sivashanmugam T, Muthukrishnan S, Umamaheswari M, Asokkumar K, Subhadradevi V, Jagannath P, et al. Discovery of potential cholesterol esterase inhibitors using in silico docking studies. Bangladesh J Pharmacol 2013;8:223-9.

26. Matsui T, Ueda T, Oki T, Sugita K, Terahara N, Matsumoto K. Alphaglucosidase inhibitors action of natural acylated anthocyanins. 1. Survey of natural pigments with potent inhibitory activity. J Agric Food Chem 2001;49(4):1948-51.

27. McDougall GJ, Stewart D. The inhibitory effects of berry polyphenols on digestive enzymes. Biofactors 2005;23(4):189-95.

28. Okoro IO, Umar IA, Atawodi SE, Anigo KM. In vitro and in vivo antihyperglycemic effect of active fraction of Cleome rutidosperma DC. Int J Pharm Pharm Sci 2015;7:289-95. 